\title{
Pitfalls in the measurement of plasma osmolality pertinent to research in vasopressin and water metabolism
}

Citation for published version (APA):

Bohnen, N., Terwel, D., Markerink, M., ten Haaf, J. A., \& Jolles, J. (1992). Pitfalls in the measurement of plasma osmolality pertinent to research in vasopressin and water metabolism. Clinical Chemistry, 38(11), 2278-2280. https://doi.org/10.1093/clinchem/38.11.2278

Document status and date:

Published: 01/01/1992

DOI:

10.1093/clinchem/38.11.2278

Document Version:

Publisher's PDF, also known as Version of record

Please check the document version of this publication:

- A submitted manuscript is the version of the article upon submission and before peer-review. There can be important differences between the submitted version and the official published version of record.

People interested in the research are advised to contact the author for the final version of the publication, or visit the DOI to the publisher's website.

- The final author version and the galley proof are versions of the publication after peer review.

- The final published version features the final layout of the paper including the volume, issue and page numbers.

Link to publication

\footnotetext{
General rights rights.

- You may freely distribute the URL identifying the publication in the public portal. please follow below link for the End User Agreement:

www.umlib.nl/taverne-license

Take down policy

If you believe that this document breaches copyright please contact us at:

repository@maastrichtuniversity.nl

providing details and we will investigate your claim.
}

Copyright and moral rights for the publications made accessible in the public portal are retained by the authors and/or other copyright owners and it is a condition of accessing publications that users recognise and abide by the legal requirements associated with these

- Users may download and print one copy of any publication from the public portal for the purpose of private study or research.

- You may not further distribute the material or use it for any profit-making activity or commercial gain

If the publication is distributed under the terms of Article $25 \mathrm{fa}$ of the Dutch Copyright Act, indicated by the "Taverne" license above, 


\title{
Pitfalls in the Measurement of Plasma Osmolality Pertinent to Research in Vasopressin and Water Metabolism
}

\author{
Nicolaas Bohnen, ${ }^{1}$ Dirk Terwel, Marianne Markerink, Jeroen A. Ten Haaf, and Jellemer Jolles
}

The reliability of measurements of plasma osmolality is known to be biased by technical artifacts, such as the anticoagulant and the osmometric technique used; the resulting measurement errors therefore may cause errors in interpretation of data. In assessing the potential biasing influence of procedural variables, we found that the temperature at which fresh plasma samples were stored, the duration of storage, and the freezing and thawing of samples appeared to significantly $(P<0.01)$ affect osmolality values around the narrow physiological range. These factors should be considered in the interpretation of studies on the osmoregulation of vasopressin secretion. In particular, the results suggest that data obtained for any but fresh samples, whether frozen-thawed samples or samples stored at room temperature, are unreliable.

Additional Keyphrases: osmometry - asmoregulation - sample handling : variation, source of

Although freezing-point determinations of plasma have been performed since the turn of the century ( 1$)$, the problem of precisely measuring plasma osmolality has not been studied extensively. Because a small change in asmolality of $\sim 12 \mathrm{mmol}$ (285-297 $\mathrm{mmol} / \mathrm{kg}$ ) may cover a $400-800 \%$ change in the plasma concentration of vasopressin (VP) $(2,3)$, a reliable measurement of osmolality is of crucial importance in research in which the concentrations of VP are related to osmolality. Robertson (2) stresses the importance of taking great care in measuring osmolality: freezing the sample or using less-precise methods such as vapor-pressure osmometry can lead to erroneous results. In addition, Bevilacqua et al. (4) warn against artifacts caused by using serum instead of plasma, and of variations caused by poor calibration of the osmometer. Morton et al. (5) reported that sodium heparin biased the measurement of plasma sodium, but not that of plasma osmolality. Redetzki et al. (6), who found unspecific increases in osmolality when whole-blood samples were stored for 1- $4 \mathrm{~h}$ at room temperature before serum was separated, demonstrated that this increase was related to the

Department of Neuropsychology \& Psychobiology, University of Limburg, Maastricht, The Netherlands.

${ }^{1}$ Address correspondence to this author at: Department of Health Sciences Research, Mayo Clinic, Rochester, MN 55905.

Received April 15, 1992; accepted June 23, 1992. production of lactic acid by the persisting glycolytic activity of blood cells.

However, no experiments have been done so far that investigate the influence of storage time and temperature on osmolality of plasma samples. In this study, therefore, we examined variables that might influence the measurements, such as storage time, temperature, and analysis of fresh samples vs frozen and thawed samples.

\section{Materials and Methods}

Venous blood was collected in evacuated plastic lithium-heparin-containing tubes (lithium-heparin 143 USP units in $10 \mathrm{~mL}$ tube; Greiner Austria) and centrifuged for $10 \mathrm{~min}$ at $1000 \times \mathrm{g}$. Plasma was separated without delay. Osmolality was measured by freezing-point depression. The glassware of the sensor of the osmometer (Osmomat 030; Gonotec Gesellschaft für Mess- und Regeltechnik GmbH, D-100 Berlin 62, Germany) was repeatedly rinsed with doubly distilled water and dried with fiber-free tissue. The osmometer was calibrated with $150 \mathrm{mmol} / \mathrm{LaCl}\left(300 \mathrm{mmol} / \mathrm{kg} \mathrm{H} \mathrm{H}_{2} \mathrm{O}\right)$ and doubly distilled water $\left(0 \mathrm{mmol} / \mathrm{kg} \mathrm{H}_{2} \mathrm{O}\right)$ for every series of determinations. The long-term (up to one month) variation of a calibrated standard was $<0.5 \%$. The vials (Gonotec) containing the $\mathrm{NaCl}$ standard were opened, $50-\mu \mathrm{L}$ samples were removed, and the vials were discarded. Calibrations were done in triplicate by assaying the standard $\mathrm{NaCl}$ samples before each series of measurements; the plasma samples were also measured in triplicate. The median value was taken as the final value because of the ordinal scale of the readings. When the intrasample deviation within the three separate measurements exceeded $3 \mathrm{mmol} / \mathrm{kg} \mathrm{H} \mathrm{H}_{2} \mathrm{O}$, the sample was measured five times and that median value was used.

The effect of the temperature of fresh plasma samples and the duration of storage on osmolality values were assessed as follows: Venous blood was withdrawn from eight healthy volunteers $(10 \mathrm{~mL}$ each), and the blood from each individual was divided into two portions. One portion was centrifuged and stored in plastic tubes at $4^{\circ} \mathrm{C}$; the other was centrifuged and stored at ambient temperature $\left(21-24^{\circ} \mathrm{C}\right)$. Osmolality was determined in $50-\mu \mathrm{L}$ portions of each sample at $0,3,6$, and $24 \mathrm{~h}$ after plasma separation. The maximal time between blood sampling and the end of centrifugation was $30 \mathrm{~min}$.

The effect of freezing-thawing of samples was as- 


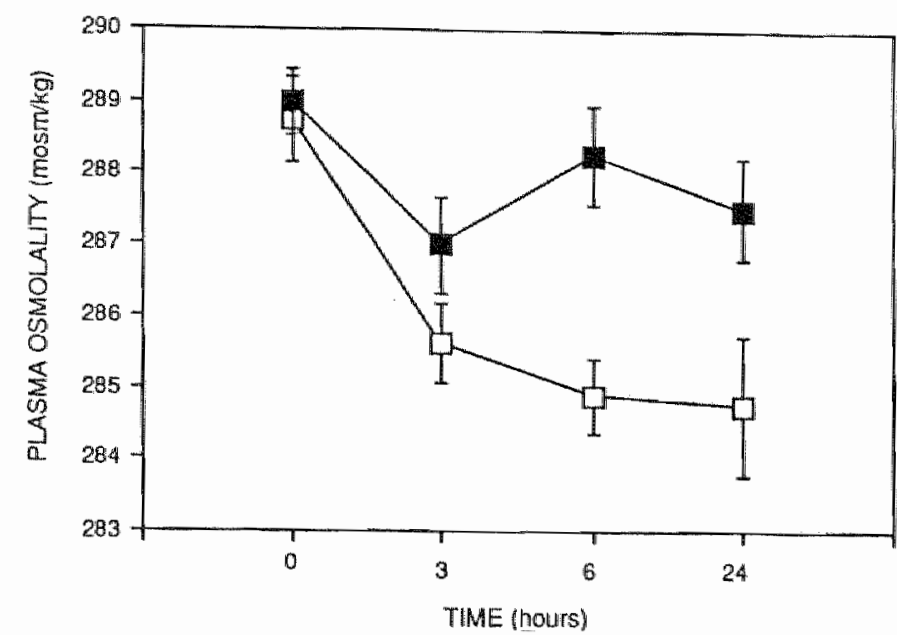

Fig. 1. Effects of storage time at ambient (ㅁ) and cool (濖) temperature on plasma osmolality (mean $\pm \mathrm{SE}$ )

sessed with plasma obtained from 28 neurological patients, whose conditions could not be expected to alter osmolality pathologically. Their plasma samples were divided into two portions: one portion was assayed immediately after plasma separation, the other after freezing-thawing (after 1-6 months of storage at $-20^{\circ} \mathrm{C}$ ). All sample tubes were tightly stoppered, and all samples were well homogenized after thawing. The frozen samples were not centrifuged after thawing and mixing; however, we saw no evidence of clotting or particulate material after the mixing.

The data were analyzed with standard statistical tests, such as the Pearson correlation test and repeatedmeasures analysis of variance with contrasts (7). P $<0.05$ was considered significant.

\section{Results}

The intra-assay CV was $1.18 \%$ for repeated measurements of a plasma sample within the same assay $(\mathbf{n}=$ 28). When each sample was measured in triplicate within the same assay, the intra-assay CV of the median value was $0.18 \%(n=28)$. The interassay $C V$ for plasma samples was not assessed because of the possible effects of storage. The interassay $\mathrm{CV}$ of the $150 \mathrm{mmol} / \mathrm{L}$ $\mathrm{NaCl}$ standards was $0.31 \%$ for the median values obtained from triplicate measurements $(n=36)$.

The effect of the temperature of fresh plasma samples and the duration of storage on osmolality values is presented in Figure 1. Analysis of variance with repeated measures for the factor "time" $(0,3,6$, and $24 \mathrm{~h})$ indicated a significant overall time effect for the samples stored at ambient temperature $\left(F_{[1,5]}=29.47, P\right.$ $<0.01)$ and for the samples stored at $4^{\circ} \mathrm{C}\left(F_{\{1,5\}}=7.79\right.$, $P<0.05$ ). Analysis of variance of contrast variables indicated significantly different contrasts between the osmolality of samples stored for 0 vs 3,6 , and $24 \mathrm{~h}: F_{[1,7]}$ $=42.48, P<0.001 ; F_{[1,7]}=122.3, P<0.001$; and $F_{[1,7]}=$ $29.87, P<0.001$, respectively. For samples stored at $4{ }^{\circ} \mathrm{C}$, the difference was significant only between the osmolality of samples stored for 0 and $3 \mathrm{~h}: F_{[1,7]}=22.4$, $P<0.01$ (see Figure 1). The Pearson correlation coefficient between the osmolalities of samples measured immediately at ambient and low temperatures $\left(4^{\circ} \mathrm{C}\right)$ was $0.85(P<0.01)$.

Comparison of the values from fresh and frozenthawed samples revealed great discrepancies, with differences ranging from -14.0 to $14.0 \mathrm{mmol} / \mathrm{kg}$. The mean difference was only $0.04 \mathrm{mmol} / \mathrm{kg}$, but the standard deviation was very high $(6.2 \mathrm{mmol} / \mathrm{kg})$. In particular, the osmolality value for 11 of the 28 frozen-thawed samples deviated $\geq 4-14 \mathrm{mmol}$ from the corresponding values of freshly measured samples. In contrast, the standard deviation of the mean difference between fresh samples measured in duplicate was strikingly lower (1.3 $\mathrm{mmol} / \mathrm{kg}$ ) and was confined to a small range: -3.0 to 3.0 $\mathrm{mmol} / \mathrm{kg}$. The Pearson correlation coefficient between osmolalities measured for fresh ws frozen-thawed samples was not statistically significant $(r=0.29 ; P>0.05)$.

\section{Discussion}

In healthy, well-hydrated individuals, plasma osmolality and sodium rarely deviate by $>1-2 \%$ from the basal values of $-287 \mathrm{mmol} / \mathrm{kg}$ and $140 \mathrm{mmol} / \mathrm{L}$, respectively. Above a threshold of $\sim 287 \mathrm{mmol} / \mathrm{kg}(2,3)$, plasma VP concentrations increase very steeply in direct proportion to plasma osmolality. The sensitivity of the mechanism is such that changes in osmolality of only $1 \%\left(-2.9 \mathrm{mmol} / \mathrm{kg} \mathrm{H} \mathrm{H}_{2} \mathrm{O}\right)$ are sufficient to alter VP by $1 \mathrm{ng} / \mathrm{L}$, i.e., by $-100 \%$ or more of its basal values ( 3 , 4,8 ); this variation may have marked effects on urine concentrations. Therefore, it is essential to achieve an intra-assay $\mathrm{CV}$ for osmolality of $<0.33-0.40 \%$ (i.e., $\sim 1$ $\mathrm{mmol} / \mathrm{kg}$ ). Triplicate measurements increased the reliability of the measured osmolality values within the same assay (intra-assay $\mathrm{CV}<0.2 \%$, i.e., $<1 \mathrm{mmol} / \mathrm{kg}$ ), whereas intra-assay $\mathrm{CV}$ with single measurements was $1.2 \%$, well above the optimal CV of $0.33-0.40 \%$.

Storing the sample for $3 \mathrm{~h}$ at ambient temperature or at $4{ }^{\circ} \mathrm{C}$ induces a mean decrease in osmolality of $\sim 3$ and $2 \mathrm{mmol} / \mathrm{kg}$, respectively, with individual differences of up to $5 \mathrm{mmol} / \mathrm{kg}$. Surprisingly, the osmolality of samples stored at $4^{\circ} \mathrm{C}$ for 6 and $24 \mathrm{~h}$ did not deviate from control values (fresh samples measured immediately) by more than the osmolality of samples stored for $3 \mathrm{~h}$. Perhaps the appearance of microaggregates in stored plasma contributes to the observed stabilization in osmolality (4); alternatively, the initial decrease in plasma osmolality may be caused by changes in the $\mathrm{pH}, \mathrm{CO}_{2}$, concentration of lactic acid, or the binding of electrolytes to protein $(9,10)$.

Osmolality values obtained for frozen-thawed samples were not significantly correlated with those for fresh samples measured immediately, with absolute individual differences deviating by as much as \pm 14 mmol. We found that results for frozen-thawed samples had to be considered unreliable in nearly $50 \%$ of the samples we assayed. Therefore, one can question whether plasma after freezing and thawing is still really plasma.

In summary, it is necessary to measure fresh plasma samples in triplicate immediately after plasma separa- 
tion. Material that has been stored or frozen may not yield reliable data. For most routine applications, storage of the samples at $4{ }^{\circ} \mathrm{C}$ may be adequate.

\section{References}

1. Veit d. Untersuchungen über den osmotischen Druck zwischen Mutter und Kind. Z Geburtshilfe Gynaekol 1900;42:316-29.

2. Robertson GL. Thirst and vasopressin function in normal and disordered states of water metabolism. J Lab Clin Med 1983;101: $351-71$

3. Robertson GL. Osmoregulation of thirst and vasopressin secretion: functional properties and their relationship to water balance. In: Schrier FW, ed. Vasopresein. New Tork: Raven Press; 1985: $203-12$.

4. Bevilacqua $M$, Meroni $R$, Dagani $R$, Renesto Norbiato GE, Baruto $C_{\text {, Norbiato }}$. Role of blond osmolality in the regulation of vasopressin gecretion in men: application of a new radioimmuno- assay method for vasopressin. J Endocrinol Invest 1985;8:97-101. 5. Morton J, Kelly JM, Teare JP. Effect of sodium heparin on measurements of osmolality and sodium in blood. Chin Chem $1988,34: 1522-3$

6. Redetaki HM, Hughes JR, Redetaki JE. Differences between serum and plasma osmolalities and their relationship to lactic acid values. Proc Soc Exp Biol Med 1972;139:315-8.

7. SAS user's guide: statistics. Version 2. Cary, NC: SAS Institute Ine. 1985.

8. Robertson GL, Athar S. The interaction of blood osmolality and blood volume in regulating plasma vasopressin in man. $J$ Clin Endocrinol Metab 1976;42:613-20.

9. Böning $D$, Maassen $N$. Blood osmolality in vitro: dependence on $p \mathrm{CO}_{2}$, lactic acid concentration and $\mathrm{O}_{2}$ saturation. J Appl Physiol $1983 ; 54: 118-22$

10. Böning D, Vaas A, Braumann K-M. Blood osmolality during in vivo changes of $\mathrm{CO}_{2}$ pressure. J Appl Physiol 1983;54:123-9.

\title{
Abbott IMx and Serono MAlAclone Assays Compared for Lutropin Determinations in Urine
}

\author{
Peter Weiss, ${ }^{1}$ Herbert Zech, ${ }^{2}$ Hans Peter Schönholzer ${ }^{3}$ and Heinz Fritzsche ${ }^{1}$
}

The urinary lutropin (luteinizing hormone; LH) profiles of 20 patients were determined in 10 consecutive urine samples $(n=200)$ with a manual technique (MAIAclone, Serono; $y$ ) and a fully automated (Abbott IMx; $x$ ) technique. For 132 single determinations within the range of detection, the regression line was $y=1.39 x-0.07(r=$ 0.85 ). Retrospective analysis of the $\mathrm{LH}$ profilles obtained by the IMX yielded the classification "not pregnant" (negative) in 14 cases, of which 13 were correctly classified; 6 profiles were classiffed as "pregnant" (positive), which correlated with the clinical findings in 4 cases. Nine of the LH profiles analyzed with the MAIAclone method were classified as negative, which was correct in seven cases. Retrospective analysis of $11 \mathrm{LH}$ profiles established with the MAIAclone assay gave positive results, which agreed with the clinical outcome in three cases. The diagnostic sensitivity of the IMX and MAIAclone methods was $87 \%$ and $47 \%$, respectively; diagnostic specificity was $80 \%$ and $60 \%$, respectively. In smaller series ( $\leqslant 40$ samples), the IMx method has considerabie advantages over the MAlAclone method in cost and convenience, because standard curves can be stored and assays can be performed as single determinations.

Addltional Keyphrases: monitoring pregnancy ' immunoradiometric assay . immumoenzymometric assay

\footnotetext{
${ }^{1}$ Nuklearmedizinische Abteilung des Landeskrankenhauses Feldkirch, RIA-Labor, Carinagasse 47, A-6800 Feldkinch, Austria.

Institut für In-Vitro-Fertilisierung und Embryotransfer, Römerstr. 2, A-6900 Bregenz, Austria.

${ }^{3}$ Neu-Technikum, CH-9470 Buchs, Switzerland.

Received September 18, 1991; accepted February 21, 1992.
}

The use of highly specific monoclonal antibodies for determination of luteinizing hormone ( $\mathrm{LH}$; lutropin) avoids the occurrence of cross-reactions, e.g., with human chorionic gonadotropin (hCG) $(1,2){ }^{4}$ This is a great advantage in monitoring $\mathrm{LH}$ concentrations as part of assisted reproduction, particularly for in vitro fertilization (IVF), because LH concentrations can be measured until shortly before follicle aspiration even in the presence of relatively high hCG concentrations. From the profile of changes in LH concentration a decision can be made before follicular puncture as to whether the follicular phase was intact or disturbed (3); in the latter case, the patient can be spared an unnecessary procedure. ${ }^{5}$ If pharmacologically stimulated follicular growth proceeds undisturbed, the final maturation phase of the ovum is (for logistical reasons) induced by $\mathrm{hCG}$, and follicle puncture is carried out $34-36 \mathrm{~h}$ later. ${ }^{2}$

Measurement of $\mathrm{LH}$ in urine has great advantages over serum estimations in clinical practice: patients can collect their own urine samples at home and avoid visits to the office for blood sampling. Previous studies have shown that specific LH profiles, evaluated by discriminant analysis, can be important for the success of hormone therapy (4). Determination of the urinary LH

\footnotetext{
"Nonstandard abbreviations: LH, luteinizing hormone; hCG, human chorionic gonadotropin; IVF, in vitro fertilization; and FSH, follicle-stimulating hormone.

${ }^{5}$ Maroulis GP, Emery M, Verkauf $B_{1}$ Cohen A. Significance of serum $\mathrm{LH}$ before and after hCG in low dose Pergonal follicular stimulation for TVF. In: 5 th World Congress on In Vitro Fertilization and Embryo Transfer, Norfolk, American Fertilization Society, $1987 ; 24$.
} 